\title{
Type-2 DM and Its Complication and Relationship among the Patients at Rajshahi Diabetes Association General Hospital: Socio-demographic Characteristics
}

DOI: https://doi.org/10.47175/rissj.v2i4.322

\section{| Farzana Ferdousi Shanta ${ }^{1}$ | Deepa Biswas ${ }^{2}$ |}

${ }^{1}$ Nursing Instructor, Enam Nursing College, Savar, Dhaka, Bangladesh

${ }^{2}$ Lecturer in Nursing, Enam Nursing College, Savar, Dhaka, Bangladesh

\begin{abstract}
The aim of this cross-sectional study of Type-2 diabetes mellitus and its complication among the patients admitted in Rajshahi Diabetes Association General Hospital and its relationship with their socio-demographic characteristics. Total fifty (50) respondents were selected for the study. Complication of Type-2 diabetes mellitus were mainly investigated. The instrument developed by the researcher was divided into 2 sections including, 1) Demographic questionnaire. 2) Question regarding complications of type-2 diabetes mellitus patients. The main findings of this thesis are that the proportion of complication of type-2 diabetes mellitus patients. The age of the respondents which $14 \%$ were between $31-40$ years of age about $30 \%$ between 41-50 years, about $40 \%$ between $51-64$ years, $16 \%$ between $65-90$ years. Type of family 46 (92\%) were the members of nuclear family $4(8 \%)$ were the member of joint family. This study would like to examine the respondents' ratings of different religions who were married or divorced. Socio-economic status 74\% were poor, 26\& respondents were middle. For this purpose, this study would like to investigate the complication of type 2 diabetes mellitus patients; the ratings of nephropathy, hypertension, the loss of sensation, heart problem, homeopathy, and Kobiraji treatment. KEYWORDS

Type II Diabetes Mellitus; Socio-demographic Characteristics, Patients; Macro and Micro Vascular Complications; Retinopathy and Nephropathy.
\end{abstract}

\section{INTRODUCTION}

Diabetes is a chronic disease characterized by improper glucose, protein, and fat metabolism. Diabetes incidence among urban residents has increased markedly in the past two decades. The number of diabetics is expected to rise from 135 million in 1995 to 171 million in 2000, 300 million in 2025, and 366 million in 2030. (King et al., 1998; Wild et al., 2004). By 2025, diabetes will be the most common disease in India, China, and the US (WHO,1998). A 170 percent rise from 84 million in 1995 to 228 million in 2025 is anticipated in emerging nations (WHO, 1998). Taiwan, Hong Kong, Singapore, and Mauritius have been recognized as having the highest prevalence of newly diagnosed diabetes patients (Zimmet, 2000).

\section{Types of Diabetes Mellitus}

Type- 1 diabetes is an autoimmune illness in which the pancreas produces very little or no insulin. Type 1 diabetes typically develops in children or young adults under the age of 20 . Some scientists believe Type 1 diabetes is a hereditary disease where pancreatic cells are assaulted and eventually die. Because the pancreatic insulin-producing cells are gone, 
individuals with type-1 diabetes will always require insulin injections or an insulin pump. Exercise and nutrition are required in addition to insulin treatment to avoid blood sugar swings. (Oftalmol, AB, 2010Type-2 diabetes is often seen in elderly overweight individuals. In certain countries, such as the United States, more children and young people are being diagnosed with Type-2 diabetes due to insufficient physical exercise. Type-2 diabetes mellitus affects $90 \%$ of diabetics. Diabetes prevalence is expected to rise from 4\% in 1995 to $5.4 \%$ by 2025 . The WHO predicts that poorer nations will bear the main cost.

\section{Micro Vascular Complication}

Rheumatoid arthritis (RA) is a microvascular disorder. Diabetes retinopathy is caused by long-term hyperglycemia damaging the retina's microvascular system. An example of diabetic neuropathies is peripheral neuropathy. Peripheral, autonomic, proximal, and focal. Each affects various areas of the body. Diabetic foot ulcers occur due to improper pressure distribution. Early diagnosis of diabetic neuropathy reduces foot ulcer hospitalization and amputations. (Leung GM, Lam K. HKMJ 2000)

\section{Macro Vascular Complications}

Diabetes mellitus is an independent risk factor for the development of atherosclerosis. Depression is twice as prevalent among diabetics as in the general population, and severe depression affects $15 \%$ of diabetics. Erectile dysfunction is another diabetes consequence.

\section{Risk Factors for Type-2 Diabetes Mellitus:}

Individual risk factors for type-2 diabetes mellitus include:

1. Weight (a body mass index of $25 \mathrm{~kg} / \mathrm{m}^{2}$ more)

2. Low physical activity

3. A family history of type-2 diabetes mellitus

4. A history of gestational diabetes.

WHO diabetes diagnostic criteria:

\begin{tabular}{|l|l|l|l|l|}
\hline Condition & 2-hour glucose & Fasting glucose & $\mathbf{H b A}_{\mathbf{1 C}}$ & \\
\hline Unit & $\mathrm{mmol} / \mathrm{l}(\mathrm{mg} / \mathrm{dl})$ & $\mathrm{mmol} / \mathrm{l}(\mathrm{mg} / \mathrm{dl})$ & $\mathrm{mmol} / \mathrm{mol}$ & DCCT \% \\
\hline Normal & $<7.8(<140)$ & $<6.1(<110)$ & $<42$ & $<6.0$ \\
\hline $\begin{array}{l}\text { Impaired fasting } \\
\text { glycaemia }\end{array}$ & $<7.8(<140)$ & $\geq 6.1(\geq 110) \&<7.0(<126)$ & $42-46$ & $6.0-6.4$ \\
\hline $\begin{array}{l}\text { Impaired glucose } \\
\text { tolerance }\end{array}$ & $\geq 7.8(\geq 140)$ & $<7.0(<126)$ & $42-46$ & $6.0-6.4$ \\
\hline Diabetes mellitus & $\geq 11.1(\geq 200)$ & $\geq 7.0(\geq 126)$ & $\geq 48$ & $\geq 6.5$ \\
\hline
\end{tabular}

\section{RESEARCH METHODS}

This study aimed to assess the prevalence of type 2 diabetes and associated complications among patients admitted to Rajshahi Diabetes Association General Hospital. The material in this research used the research strategy, demographic, study location, sample, equipment, data collecting and analytic procedures. The type of the study is a cross sectional type of descriptive study. This research was done in Rajshahi Nursing College. All the type-2 diabetes mellitus people residing at Rajshahi Diabetes Association General Hospital, Rajshahi was be sample population. Sample Techniques is Purposive sampling technique. Technique of Data Collection used Face to face formal interview. The Instrument of the Study is Partially structure questionnaire. 
Variables of the Study

$\square$ Age

- Sex

Type of Family

Educational status

- Marital status

ㄱeligion

$\square$ Occupation

$\square$ Socio-economic status

Dependent Variable

Complications of type 2 diabetes.

RESULTS AND DISCUSSION

Patient's Demographic Information

Table 1. Distribution of the respondents by age

\begin{tabular}{|l|l|c|l|}
\hline Variable & Parameters & $\mathbf{N = 5 0}$ & $\mathbf{\%}$ \\
\hline \multirow{4}{*}{ Age } & $18-30$ years & 0 & $0 \%$ \\
\cline { 2 - 4 } & $31-40$ years & 7 & $14 \%$ \\
\cline { 2 - 4 } & $41-50$ years & 15 & $30 \%$ \\
\cline { 2 - 4 } & $51-64$ years & 20 & $40 \%$ \\
\cline { 2 - 4 } & $65-90$ years & 8 & $16 \%$ \\
\hline
\end{tabular}

50 patients were selected for study the age of which respondents $14 \%$ were between 31 40 years of age, about $30 \%$ between $41-50$ years, about $40 \%$ between $51-64$ years, $16 \%$ between 65-90 years respectively.

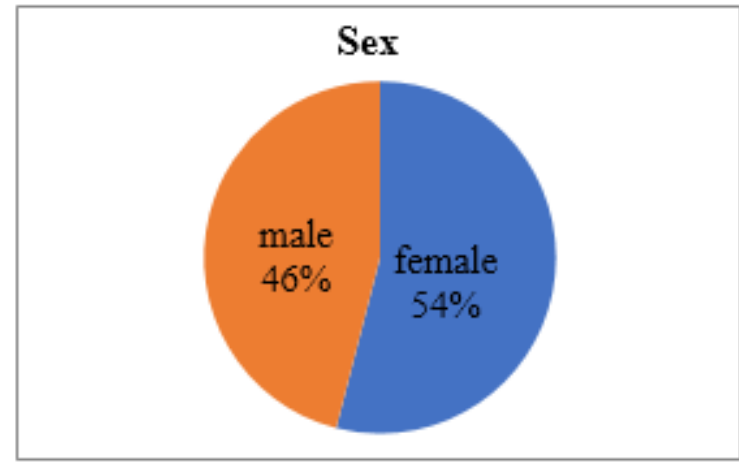

Figure 1. Sex: Distribution of the respondents by sex

The patients are presented by man than women among the 50 the sexes of the respondents were $54 \%$ ( 27 person) female and $46 \%$ ( 23 person) male.

Table 3. Distribution of the respondents by socio-economic status

\begin{tabular}{|l|l|c|c|}
\hline Variables & Parameters & $\mathbf{N - 5 0}$ & \% \\
\hline \multirow{2}{*}{$\begin{array}{l}\text { Socio-economic } \\
\text { status }\end{array}$} & $1-15000$ & 37 & $74 \%$ \\
\cline { 2 - 4 } & $15001-30000$ & 13 & $26 \%$ \\
\cline { 2 - 4 } & 300001 to above & 0 & $0 \%$ \\
\hline
\end{tabular}


Most of the sample from the sample which is $37(74 \%)$ were poor.13 (26\%) respondents were middle and there was no rich respondent found in my study.

Table 4. Distribution of the respondents by occupation

\begin{tabular}{|l|l|c|c|}
\hline Variables & Parameters & N-50 & \% \\
\hline Occupation & Jobless & 0 & $0 \%$ \\
\cline { 2 - 4 } & Student & 0 & $0 \%$ \\
\cline { 2 - 4 } & Housewife & 22 & $44 \%$ \\
\cline { 2 - 4 } & Businessman & 5 & $10 \%$ \\
\cline { 2 - 4 } & Service & 6 & $12 \%$ \\
\cline { 2 - 4 } & Agricultural worker & 14 & $28 \%$ \\
\cline { 2 - 4 } & Others & N-50 & $6 \%$ \\
\hline
\end{tabular}

Result shows that 22 respondents which were $44 \%$ worked as a housewife. 5(10\%) respondents were businessman.6 (12\%) respondent were involving in service.3 (6\%) respondent were involving in others. There was no student and jobless found in my study.

Table 5. Distribution of the respondent by some type-2 DM relevant variable

\begin{tabular}{|l|c|c|c|c|}
\hline Parameter & \multicolumn{4}{|c|}{ Answer } \\
\hline & $\begin{array}{l}\text { No. of } \\
\text { Frequency }\end{array}$ & & $\begin{array}{l}\text { No. of } \\
\text { Frequency }\end{array}$ & \\
\cline { 2 - 5 } & Yes & $\%$ & NO & $\%$ \\
\hline Take diabetes medication & 49 & 98 & 1 & $22 \%$ \\
\hline Take diabetes medication regularly & 39 & 78 & 11 & $22 \%$ \\
\hline Complication of type-2 DM & 47 & 94 & 3 & $6 \%$ \\
\hline Diabetes remain control & 17 & 34 & 33 & $66 \%$ \\
\hline Maintain diabetic diet & 29 & 58 & 21 & $42 \%$ \\
\hline Know treatment of type-2 DM & 50 & 100 & 0 & $0 \%$ \\
\hline Take advice regularly from doctor & 29 & 58 & 21 & $42 \%$ \\
\hline
\end{tabular}

This table is shows that majority of the respondents were $98 \%$ yes, $2 \%$ no answer. (Take diabetes medication) $78 \%$ yes, $22 \%$ no answer. (Take diabetes medication) regularly $94 \%$ yes, $6 \%$ no answer. (Complication of type-2 DM)34\% yes, 66\% no answer. (Diabetes remain control) $58 \%$ yes, $42 \%$ no answer. (Maintain diabetic diet) $100 \%$ yes $\%$ no. (Know treatment of type-2) DM 58\% yes, $42 \%$ no (Take advice regularly from doctor).

Table 6. Distribution of the respondent by some type-2 DM relevant variable

\begin{tabular}{|l|c|c|c|c|l|l|}
\hline \multirow{2}{*}{ Variable } & \multicolumn{7}{|c|}{ Answer } \\
\cline { 2 - 7 } & $\begin{array}{l}\text { No. of } \\
\text { Frequency }\end{array}$ & & $\begin{array}{l}\text { No. of } \\
\text { Fre- } \\
\text { quency }\end{array}$ & $\begin{array}{l}\text { No. of } \\
\text { Fre- } \\
\text { quency }\end{array}$ & \\
\cline { 2 - 8 } & Yes & $\%$ & No & $\%$ & $\begin{array}{l}\text { Don't } \\
\text { know }\end{array}$ & $\%$ \\
\hline Do you have cataract or retinopathy? & 10 & $20 \%$ & 40 & $80 \%$ & 0 & $0 \%$ \\
\hline Do you have nephropathy? & 8 & $16 \%$ & 42 & $84 \%$ & 0 & $0 \%$ \\
\hline Hypertension & 14 & $28 \%$ & 36 & $72 \%$ & 0 & $0 \%$ \\
\hline Do you have numbness in your feet? & 14 & $90 \%$ & 5 & $10 \%$ & 0 & $0 \%$ \\
\hline Do you have heart problem? & 45 & $4 \%$ & 48 & $96 \%$ & 0 & $0 \%$ \\
\hline
\end{tabular}

This table shows that majority of the respondents had cataract $20 \%$ yes, $80 \%$ no, $80 \%$ no, $0 \%$ don't know answer; Nephropathy $16 \%$ yes, $84 \%$ no, $0 \%$ don't know answer; numbness 
on feet $90 \%$ yes, $10 \%$ no, o\% don't know answer. Heart problem $4 \%$ yes, $96 \%$ no,o\% don't know answer; Hypertension $28 \%$ yes, $72 \%$ no ,o\% don't know answer.

Table 7. Distribution of the respondent by some type-2 DM relevant variable

\begin{tabular}{|l|l|c|c|}
\hline Variable & Parameter & $\mathbf{N - 5 0}$ & $\mathbf{\%}$ \\
\hline \multirow{3}{*}{$\begin{array}{l}\text { What kind of medication have you } \\
\text { taken? }\end{array}$} & Oral medication & 9 & $18 \%$ \\
\cline { 2 - 4 } & Insulin & 41 & $82 \%$ \\
\hline \multirow{4}{*}{ How long you suffer from DM? } & $1-5$ years & 13 & $26 \%$ \\
\cline { 2 - 4 } & $5-10$ years & 8 & $16 \%$ \\
\cline { 2 - 4 } & 10 to above years & 24 & $48 \%$ \\
\cline { 2 - 4 } & Don't know & 5 & $10 \%$ \\
\hline \multirow{4}{*}{ Treatment of type-2 DM } & Hospital & 45 & $93 \%$ \\
\cline { 2 - 4 } & Homeopathy & 2 & $44 \%$ \\
\cline { 2 - 4 } & Kobiragi & 0 & $0 \%$ \\
\cline { 2 - 4 } & Others & 0 & $3 \%$ \\
\hline
\end{tabular}

This table shows that the respondents were take oral medication $18 \%$, insulin $82 \%$, suffer from DM $26 \%$ are 1 to 5 years, $16 \%$ suffers from DM 5 to 10 years, $48 \%$ suffer from DM above 10 years, $10 \%$ were don't know. Take the treatment from hospital $90 \%$, homeopathy $4 \%$ and kobiragi $0 \%$, others $3 \%$.

\section{CONCLUSION AND RECOMMENDATION}

At the end, the result on type- II Diabetes Mellitus and its Complication among the Patients indicates that maximum Patients' of Rajshahi Diabetes Association General Hospital had complication. Majority of the respondents were numbness/ tingling or loss of sensation on their feet, minority of the patients were heart problem, eye problem and kidney problem. Patients should be informed about lifestyle modifications that may help avoid diabetes and coronary artery disease, such as weight management, increased activity, and quitting smoking.

\section{REFERENCES}

King, II, Aubert, R. E. and Herman, W. H. (1998). Global Burden diabetes, 1995-2025: Prevalence, numerical estimates and projections. Diabetes Care, 2(9), 1414-1431.

Leung, GM and Lam, K. (2000). HKMJ, 6: 61-68.

Oftamol, AB. (2010). Prevalence of Diabetes retinopathy in newly diagnosed type 2 diabetes mellitus in the city of Luzerna-SC, 73(3): 259-265.

WHO. (1998). Global burden of diabetes: WHO projects a $17 \%$ of growth in the number of people with diabetes in developing countries by 2025 .

Wild, S. Roglic, G., Sicree, R. and King, H. (2004). Global Prevalence of diabetes: Estimates for the year 2000 and projections by 2030. Diabetes Care, 27(5): 1047-1053.

Zimmet, P. (2000). Globalization, coca-colonization and the chronic disease epidemic: Can the Doomsday scenario be averted? International Journal of Medicine. 247: 301-310. 